\title{
Reclaiming the Space of Social Entrepreneurship: A Case from Cosmetology Industry
}

\author{
R. K. N. D. Darshani \\ Department of Human Resource Management, University of Kelaniya, Sri Lanka \\ niroshidarshani@gmail.com
}

\begin{abstract}
The concept of social entrepreneurship has been differently identified by diverse researchers leading to contradicting definitions. Therefore, claiming social entrepreneurship is still questionable in literature. As an answer to this contradicting findings and ideas of social entrepreneurship in literature, the current case study focused in explaining the social entrepreneurial characteristics and the behavior in cosmetology industry since very little attention has been given to cosmetology firms when recognizing social entrepreneurial ventures. There, the case study highlights the social entrepreneurial features are exist in cosmetology firms and addresses local efforts by targeting problems that have a local expression with a global relevance. Moreover, the case study elaborates how the firm tackle unmet socio-economic needs with an innovative way.
\end{abstract}

Keywords: Cosmetology, Social Entrepreneurship, Social Needs, Innovation

\section{Introduction}

It is proven that the entrepreneurial activities by new and established companies are major sources of wealth and job creation, economic and technological growth, and social transformation (Bhide, 2000). There, most recent studies have shown that the field of social entrepreneurship has grown exponentially in recent years and has become a social, economic and cultural phenomenon. In light of the several issues such as economic crisis, the inability of some governments to meet the social needs of their constituencies, continuously widening gap between rich and poor in many developed countries, and for many a less than appealing, scandal-ridden corporate world, the stories of individuals and groups of individuals who want 'to change the world' (Bornstein, 2004) are inspiring. According to Pless (2012), the examples of dedicated and visionary entrepreneurs who design solutions 
for unmet social needs, and whose primary intention is to help others, are a source of hope in markets where traditional forms of capitalism are struggling to rebuild their reputation and legitimacy.

Currently, the contribution which social entrepreneurs make to a nation's social, economic, cultural and environmental wealth is being increasingly recognized. Hence, social entrepreneurship has been identified as an innovative way of tackling unmet socio-economic needs (Mulgan \& Landry, 1995; Leadbeater, 1997, as cited in Shaw, 2007). The term "social entrepreneurship" has emerged as a new label for describing the work of community, voluntary and public organizations, as well as private firms working for social rather than for-profit objectives. Delineating, social entrepreneurship has evolved into the mainstream after years of marginalization on the edges of the non-profit sector. After all, Social entrepreneurs recognized as the entrepreneurs who are able to serve a triple bottom line achieving profitability, societal impact and environmental sustainability, simultaneously (Harding, 2006).

Still, despite the growing international nature of many social entrepreneurial activities, researchers have not devoted sufficient attention to understanding how entrepreneurs select particular global social causes or create their ventures around these international opportunities. Researchers have also failed to articulate the rationale for the emergence of new international social ventures or the timing and scope of their international operations (Zahra et al., 2008). Yet, Dacin et al. (2011) clearly stated that social entrepreneurs' pursuit profitability or other objectives.

Identifying the different phenomena on social entrepreneurship the study focuses on cosmetology industry as very little attention, particularly almost no attention has paved by the scholars on the ventures into cosmetology as social entrepreneurial ventures. Therefore, the study selects the International Academy of Beauticians (Pvt) Ltd since it satisfies the criteria of social entrepreneurial venture characteristics. 


\section{Literature Review}

\subsection{Social Entrepreneurship}

According to Austin, Stevenson, \& Wei-Skillern (2006) definitions of social entrepreneurship range from broad to narrow. Former studies refers social entrepreneurship as into innovative activity with a social objective in either the for-profit sector, such as in social-purpose commercial ventures (Dees \& Anderson, 2003; Emerson \& Twersky, 1996, as cited in Austin et al, 2006) or in corporate social entrepreneurship (Austin, Leonard, Reficco, \& WeiSkillern, 2004, as cited in Austin et al, 2006). Dees (1998) has delineated that the social entrepreneurship lies in the nonprofit sector, or across sectors, such as hybrid structural forms which mix for-profit and nonprofit approaches. As per in the narrow definition, social entrepreneurship typically refers to the phenomenon of applying business expertise and market-based skills when nonprofit organizations develop innovative approaches to earn income in the nonprofit sector (Reis, 1999; Thompson, 2002, as cited in Austin et al, 2006).

Yet, most commonly social entrepreneurship defined as "entrepreneurial activity with an embedded social purpose" (Austin et al, 2006). Mainly most approaches from different authors define social entrepreneurs as entrepreneurs with a social mission (Dees 2001; Martin and Osberg 2007, as cited in Santos, 2012) and consider social entrepreneurship as entrepreneurial activity with an embedded social purpose (Austin et al., 2006). Combination of the concepts of entrepreneurship and social mission are the common concepts in definitions of social entrepreneurship (Mair \& Marti 2006; Martin $\&$ Osberg 2007). According to Haugh (2007) social entrepreneurship has also been called the simultaneous pursuit of economic, social, and environmental goals by enterprising ventures. Yet, Dees (2001) one of the approaches offers a more idealized view of social entrepreneurs as change agents in the social sector and this approach is completely contrasts with more pragmatic definitions that delineate social entrepreneurship as the generation of earned income by ventures in the pursuit of social outcomes (Boschee, 2001, as cited in Santos, 2012). 


\subsection{Social Entrepreneurship; A Critique}

According to the definitions and the statements carried by the authors it is apparent that some authors have ignored the mission of social entrepreneurship as into associated economic outcomes, and meanwhile some other authors suggest that economic outcomes do form part of the mission of social entrepreneurship (Mair \& Marti 2006, Zahra et al., 2009). These authors do not consider the economic mission as the primary mission of social entrepreneurship yet it as a way of economic value creation after number of empirical studies outcomes.

Similarly, Dacin et al. (2010) delineated that there likely exists a hierarchical ordering of social and economic value creation. Confirming the arguments of these authors Dacin, Dacin \& Tracey (2011) argue that social entrepreneurs balance both sets of priorities and not just a one end of achieving only a social mission. They posit that a social value creation mission does not necessarily negate nor diminish a focus on economic value. In fact, economic value is most crucial for the sustainability of social entrepreneurial ventures and the creation of social value.

Further Dacin et al. (2011, p.1206) state that ... many scholars of social entrepreneurship tend to overlook those entrepreneurs that seek to maximize both social change and profitability, including entrepreneurs who focus on the symbolic management of social values to achieve their political and/or economic objectives and entrepreneurs who destroy (proactively or inadvertently) social goods through the pursuit of profitability or other objectives. An interesting example of the unintended consequences or "dark side" of social entrepreneurship is the recent criticism by Nobel laureate Muhammed Yunus, who publicly criticized organizations in the microfinance domain for marketing and privileging economic value (revenue) creation over the goal of social value creation...Further, Alvarez and Barney (2007) argues that social entrepreneurs may discover or create opportunities and launch ventures to make profits, create wealth, or balance social and economic imperatives (Elkington and Hartigan, 2008; Perrini, 2006, as cited in Zahra et al., 2008). Further, Prahalad (2006, as cited in Zahra, 2008) states that social ventures can be built by independent entrepreneurs as well as corporations. Because profit and nonprofit seeking social ventures create jobs and develop 
the institutions and infrastructures needed for development, they can be the engine of economic and social development on a global scale.

Similarly (Mair \& Marti, 2006) stressed out that social entrepreneurship can occur equally well in a new organization or in an established organization and it may be labeled "social intrapreneurship". Like intrapreneurship in the business sector, social intrapreneurship can refer to either new venture creation or entrepreneurial process innovation. Hence, the organizational context in which social entrepreneurship occurs, it can be, i.e., newly created or established organizations, sets it apart from other more loosely structured initiatives aimed at social change, such as activist movements.

These literature delineated from different authors confirms that social entrepreneur is also an entrepreneur with a common intention of making profits. And Frank Knight's risk bearing theory derives the relationship of risk, uncertainty, and profit which as entrepreneurial predominant features. (Langlois \& Cosgel, 1993).

\subsection{Social Entrepreneurship; characterization and importance}

Former, social entrepreneurship has become a mainstream after years of marginalisation on the edges of the non-profit sector. (Urban, 2008). Yet,social entrepreneurship as a practice that integrates economic and social value creation has a long heritage and a global presence.( Mair \& Marti, 2006) According to Spear (2006) models of social entrepreneurship deal with (including any external support), social capital, learning, and outcomes. And it was hypothesized that social capital might be an important resource in the social economy and similarly it led to consider the formal and informal support structures in the entrepreneurial process (even including the possibility that the entrepreneurial process might be distributed outside the boundaries of the new co-operative enterprise, for example, to include public sector or social enterprise players and agencies.

Social entrepreneurship still remains as an under-researched area with replications. (Dacin et al., 2011; Harding, 2006; Mair \& Marti, 2006). The importance of social entrepreneurship as a phenomenon in social life is critical; social entrepreneurs contribute to an economy by providing an alternative business model for firms to trade commercially in an 
environmentally and socially sustainable way. They also provide an alternative delivery system for public services such as health, education, housing and community support (Harding, 2006, p. 10).

\subsection{Social entrepreneurship; a new phenomenon}

The study of Bielefeld (Bornstein, 2004; Boschee, 2006; Brinkerhoff, 2000; Dees, Emerson, \& Economy, 2001, 2002; Robinson, 2002; Tranquada \& Pepin, 2004, as cited in Bielefeld, 2009) delineates several characteristics that can be appeared in a social entrepreneurial business as per the research studies of authors. Such characteristics are: diversify funding sources; fund overhead, innovation or unpopular causes; provide long-term sustainability; take advantage of new opportunities; meet new expectations from funders who ask nonprofits to be self-sustaining; spur the desire to meet the double-bottomline (social value and income) or the triple-bottom-line(social value, income, and environmental neutrality); create entrepreneurial spirit in the organization; show an enhanced understanding of clients (needed for commercial success); test social value; add skills and competencies to an organization and enhance an organization's profile among funders, and in the community.

It is important to note that the concept of social entrepreneurship has been differently identified by different scholars (Dees \& Elias, 1998). There, one group of researchers identifies social entrepreneurship as not-for-profit initiatives in search of alternative funding strategies, or management schemes to create social value (Austin, Stevenson, \& Wei-Skiller, 2003). Another set of scholars refers social entrepreneurship as a socially responsible practice of commercial businesses engaged in cross sector partnerships (Sagawa \& Segal, 2000; Waddock, 1988, as cited in Mair \& Marti, 2006). And a third group of researchers understands social entrepreneurship as a means to alleviate social problems and catalyze social transformation (Alvord et al., 2004).

Therefore, by analyzing the definitions which are established for social entrepreneurship and descriptions given for social entrepreneurship by different authors, Mair \& Marti (2006) have identified three views in a social entrepreneurship. First, they view social entrepreneurship as a process of creating value by combining resources in new ways which delineates on 
innovation. Second, these resource combinations are intended primarily to explore and exploit opportunities to create social value by stimulating social change or meeting social needs which delineate proving a social value and seeking opportunities. And third, social entrepreneurship involves the offering of services and products but can also refer to the creation of new organizations which talks about creation of new ventures and offerings. Further they have explained that social entrepreneurship can be occurred equally well in a new organization or in an established organization.

\section{Research Methodology}

\subsection{Paradigm}

Qualitative research can be in to any one of these three paradigms, positivist, interpretivist, and critical (Denzin \& Lincoln, 2003; Punch, 1998). Neuman (2011) distinguished interpretivism and positivism philosophical paradigms. He stated that there is an objective and behavior and cause and effect behavior rise through a positivistic view where it can be measured and through human activity can be predicted. Hence, the researcher after extensive consideration decided to move with interpretivism rather positivism, since it is more suitable and comprehensive in delineating the present research interest.

\subsection{Research Purpose: Descriptive and Exploratory}

According to Cavana et al. (2001) exploratory research aims to highlight and explore an un-explored and un-interpreted phenomenon to better understand the problem. Further they stated that such exploratory research provides indepth, rich data and descriptions.

As stated, the researcher in this study seeks to observe and examine social entrepreneurship in cosmetology firms which are in to private sector. This field is predominantly undergoes with the positivist approach and majority of previous studies tapped descriptive and exploratory approaches in delineating social entrepreneurship and its outcomes, and the behavior of social entrepreneurship in selected cosmetology firm (Seelos \& Mair, 2005; Mair \& Marti, 2006, Dees,1998). Therefore, the researcher adopted exploratory and a descriptive approach in order to delineate the consequences of the social entrepreneurship which is less studies as per in literature. 


\subsection{Research Approach: Qualitative- case study approach}

As per stated by Taylor (1984) qualitative research originates from the disciplines of education and social sciences with their studies of complex human behavior. Holloway \& Wheeler (2002) clearly stated that qualitative research allows researchers to deeply explore behaviours, different perspectives, and life experiences to discover the complexities of the situation through a holistic framework. Therefore, to answer the research questions and to illuminate the purpose of the study, the researcher chose a qualitative approach as most of the social entrepreneurship studies are into qualitative studies (Seelos \& Mair, 2005; Lesabe \& Nkosi, 2007).

Most of the researches which has studied on social entrepreneurship and its outcomes especially came up with qualitative and case study approach (Mair \& Marti, 2006, Seelos \& Mair, 2005). Hence, the researcher chose a qualitative case study approach for the study purpose.

\subsection{Selection of the sample}

The study covered a sample of leading Sri Lankan private sector cosmetology firm which is into social entrepreneurship. There the researcher identified a sample frame consist with social practices and chose IAB for the study purpose based on the alignment with the purpose of the study. According to Haugh (2007) social entrepreneurship introduced as a simultaneous pursuit of economic, social and environmental goals by enterprising ventures. Further, the ventures pursuit creating a social values are into human rights, economic fairness, equal opportunity, freedom of expression, consumer rights, environmental protection and such (Santos, 2009).

\subsection{Selection of the case}

International Academy of Beauticians (IAB) was established to deliver highly effective training programs focusing on the industry of hair dressing \& Beauty Therapy. As a small business promoting education institute it serves the unemployment condition of the country by teaching and promoting hair dressing and beauty therapy to build hairdressers \& beauty therapists.

As Santos (2009) delineated, the ventures pursuit creating a social values are into human rights, economic fairness, equal opportunity and freedom of 
expression the organization promotes small businesses and to reduce the unemployment condition by building own-small businesses by fulfilling the human right and equal opportunity to be employed as a woman or a man in the country. Further, Santos (2009) discussed that social entrepreneurs usually starts with small, local efforts and they often target problems that have a local expression but global relevance such as promoting small business creation. Hence, satisfying the definitions considered by the researcher the study sample was selected aligning with the study definition. Similarly, social entrepreneurship has been identified as an innovative way of tackling unmet socio-economic needs (Mulgan \& Landry, 1995; Leadbeater, 1997, as cited in Shaw, 2007).

Therefore, the researcher identifies International Academy of Beauticians (Pvt) Ltd being a local organization which is in to service sector representing beauty and fashion industry as an organization which address the study definition of the research study and consists with massive human involvement which lays a positive foundation to carry out the study on social entrepreneurship.

\subsection{Data collection and research instruments}

Predominantly the researcher used unstructured in-depth interviews for datagathering method. Information is then recorded on tape (with the permission from participants) in order to preserve an accurate account of the interview and can be replayed for analytic purposes. In triangulating the data collected through in depth interviews the current study gathered data through focus group discussions and observations too. Further, researcher took notes during the interviews maintaining field notes whenever necessary. Participants were informed on their right to withdraw from the study of the interview at any time before commencing the interview whenever they are reluctant to take part in. Other than to into in-depth interviews the researcher collects data from interviews, observations and focus group interviews for a comprehensive analysis of data. For ensuring profitability of the organizations the researcher used secondary data sources too. 


\subsection{Validation and Triangulation in Data Analysis}

The study used multiple methods of data gathering; interviews, focus groups, observations including key incidents and documents. Hence, the process of validation and triangulation began with the data collection. Triangulation gives an understanding to the researcher whether to be proceed with new questions that were not anticipated and thus never considered (Creswell, 2009).

For the purpose of ensuring the validity and trustworthiness of the research study, the researcher used the method of triangulation (Merriam, 2009; Schensul \& LeCompte, 2012). To triangulate the data the researcher compares and cross-checked the raw data collected during the participant interviews with documents and data records and used different sources of data collection such as in depth interviews, focus group discussions, observations along with field notes. Further, based on the thematic analysis the researcher compared and cross checked the "actual language used by the participants", hence the study analysis considered similar words or phrases to cluster under the themes. According to Creswell (2009), by establishing themes based on the different perspectives of the interview participants, the researcher not only triangulates data, but also be adding validity to the research study. Further, the study brought no violation of any ethical concern in deriving the flow of the study and use of language.

\section{Results}

It is evident that hair dressing and beauty therapy is been a lucrative business in the world especially among ladies. Therefore, it is a novel aspect to enter as an entrepreneurial business since fashion industry is ever emerging. The entrepreneur of International Academy of Beauticians has identified the market opportunity to initiate a business which serves the ladies. On one hand it is apparent that getting well dressed, having a good look and physical grooming is so important to create a good impression in others which is highly concerned by ladies for their social network and for the self-esteem. Hence, firms in the fashion industry brings a good opportunity to be get employed, especially by ladies. On the other hand, the entrepreneur believes that women should not depend on their other family members and they should be well fixed financially to be independent and to support the financial status of the 
family. Further, the entrepreneur believes that it will lead to enhance the economy of the country too. According to the entrepreneur educating the students or the customers on hair dressing and beauty therapy is a lucrative business which never falls and mushrooming new small businesses can reduce the unemployment of the country which has been a huge social issue. And it will upgrade the standard living of people. As explained by the entrepreneur;

"This is a field that is very popular among ladies. Now, ladies you know, their opportunities are sometimes restricted. Because, family, work life balance, so much of components to a woman working. Now this kind of a business is something that you can start at home. It requires a very little investment. I felt that doing something like this can definitely help the economy of the family. Even a woman can be employed at home. And it empowers. So I felt this is definitely a way to support others. Because someone can lives a good life. I have students to come and tell me, "Miss, now I have my own bank account. I have bought my own car". Because I also as a woman, I believe being independent. So I felt this is very good way to make others independent also" (Ms. Hasini, September 2015).

The statement of the social entrepreneur clearly shows that she has in intention to contribute to the employability of the country and to provide an equal opportunity to ladies in being employed. There, she has exploited the opportunity to create a social value by stimulating the meeting of social needs. In doing so, she has initiated the school of International Academy of Beauticians as an institute provides a service to the people who intent to become entrepreneurs or employees. As per the study data, the organization focuses on promoting small businesses, formal education on hair dressing and beauty therapy in order to create novel ventures, creation of individual values, upgrading the employability of the country and contribution to the economy and the society by providing a better living standard to everyone play a major role in the business. Further it confirms through the statement of;

"We [can] very proudly say we have built many entrepreneurs. The success rate of our school is very high. Almost $80 \%$. I would say even 85\%.” (Ms. Hasini, September 2015). 
Assuring the intention of the entrepreneur, a director of the company raised his voice stating that;

"This company creates a value to individuals. That is the satisfaction you can get. When you see a student getting trained in the school and then see her working in a salon that's what we want" (Mr. Shuvo, September 2015).

Similarly, the view of HR manager was;

"[...] in the same time they are doing a social service and they are contributing to the society via the business. That's why I said, they are having a different approach." (Mr. Nipuna).

As described by Mair \& Marti (2006) the businesses in the process of social entrepreneurship are creating values in a new way, meeting social needs and providing a service to the society by providing the direction to create new ventures. Further, the researchers has explained that the ventures pursuit creating a social values are into human rights, economic fairness, equal opportunity, freedom of expression, promoting small business creation (Santos, 2009) new venture creation (Mair \& Marti, 2006), education (Harding, 2006) and the creation of fresh markets and new jobs (Zahra, 2008) are in to social entrepreneurship and such organizations as social enterprises.

The director directly expressed his view on the business confirming the entrepreneur's statements. He expressed that the importance of small businesses to the country in order to enhance the financial status of the country and how it help individuals. The intention of International Academy of Beauticians as a private firm is to promote small business management and execution which lead to create entrepreneurs, to build up exciting entrepreneurs and to increase the employability of the country. Similarly, most of the employees were kept saying that IAB is the best way to become an entrepreneur or to be employed.

Equal opportunity also as a social entrepreneurial activity, a good expression was come out from an instructor of the firm about equal opportunity that provides by the organization. She explained as; 
"Normally it takes 4 or 5 years to do a make-up at a TV program with lots of experience. But, here, if the student is with that talent definitely she or he gets that chance. No barrier for that. No levels or status are considered for such a thing. Only the talent is considered. If the student is talented, then definitely she gets her place" (Ms. Samithri).

Ms. Samithri and many others stated that normally opportunities for fashion shows and TV programs are grabbed by the company owner or heads only. As they stated participating with such programs are dreams of potential entrepreneurs in the field. That apparently shows the altruistic attitude of the entrepreneur since the field is highly competitive. A skillful student or an employee can beat the teacher tomorrow in the field of fashion industry. As per the literature altruistic motive is the predominant characteristic in social entrepreneurship. Ms. Hasini clearly expressed her altruistic attitude on building entrepreneurs to the society. There, she elicits that how happy she is when students/ customers get in to a high establishment with an economic wealth.

Further, Ms. Hasini explains whenever the people are ready to do a venture in a new way, the firm is ready to offer a career either way of an entrepreneurship or as an employment in the field of fashion industry which satisfy the researchers' findings as a characteristic of a social entrepreneur (Mair \& Marti; 2006, Santos, 2009).

IAB employees are highly satisfied with the entrepreneur's and top management's management and leading style and the company where they work with. The respondents of IAB highly believe that the firm promotes small businesses through a unique and distinguishable way of education and it serves the society. Serving the society by reducing unemployment and raising the independence of women leads to economic wealth in the country and it upgrade the lives of people. IAB respondents believe that the satisfaction which gets through serving the people is much higher than the salary which earns for personal fulfillment. Hence, they believe serving people under a great entrepreneur leads to stay in the organization regardless the salary and other benefits they get. As stated by the manager;

"We get happiness by teaching a student. Our only hope is to see our students in a top level." (Ms. Chandima, September 27 $\left.7^{\text {th }}, 2015\right)$. 
The employees at IAB are highly satisfied to work in a place where they can serve the society through promoting small businesses. The respondents highly believe that the wish of every employee at IAB as the same. According to the respondents' views, IAB is the best school where a student can learn on hair dressing and beauty therapy due to distinguishable education methods including many practical and opportunities for fashion shows and TV programs. Hence, the respondents believe that the students who learn at IAB are highly employable. Therefore, the decision that they took to join with an institute where they can be employed and meanwhile they can support the society as a most accost accurate decision that they have ever got. According to Venkataraman (2002) stakeholders are connected to the entrepreneurial process once they are with the value system of the organization. In IAB, employees thoroughly believe that they are a part of the value system and it was very much clear during the empirical data collection.

Assuring others' views a trainee employee's voice was;

"Regardless the field everyone needs to work with the society. In this field it's much higher. So, here we get the happiness other than to the salary we get." (Ms. Hasara, Focus group 2, September $27^{\text {th }}, 2015$ )

It was apparent and assured that most of the respondents are happy to work in a company where they can serve the society regardless the salary they get. Because, according to the respondents the facilities and other economic and functional benefits match with the industry rates or sometimes it is below the industry rate. Yet, the willingness to work at a place which provides a better education to promote businesses brings them more pleasure than the other benefits.

According to Sharir \& Lerner (2006), the entrepreneur's social network, the composition of the venturing team (salaried versus volunteer workers) and forming long term collaborations directs at employer branding in a social entrepreneurial business. Therefore, it is proven that the social entrepreneurial activities of IAB accompany employer branding to the firm due to the fact of salaried versus volunteered workers. 
According to a Director at IAB;

"This company is creating a value to individuals. That is the satisfaction you can get. When you see a student getting trained in the school and then see her working in a salon that's what we want." (Mr. Shuvo, Focus group 2, September 27 $7^{\text {th }}, 2015$ )

As mentioned previously, the competition among rivals is massive in the industry of fashion and cosmetology and who is a student today can beat the teacher tomorrow. Therefore, employees who are in the same field do not allow others to move ahead in other institutes as explained by the respondents. Yet, IAB totally focuses at developing each other in order to provide a better live for others. The intention of the social entrepreneur is to provide a better education to people who love to initiate a business or willing to become an entrepreneur in order to fix their financial condition in the family and to serve the economy of the country. The entrepreneur also believes that the employees willingly work at the organization due to the social entrepreneurial activities regardless personal benefits that the employees could attain from the company.

"I have seen them, I mean whenever I tell them, "can you help me in this", and they never hesitate. So I think whether it is professionally within the business or outside of the business, they have gone beyond their work." (Social entrepreneur, Ms. Hasini, September 2015).

As per the data collected from social entrepreneur, she has observed the behaviors of employees in different situations. As the respondents explained, they always have to go out for different programs and have to stay until late nights or days out of the family. Yet, they voluntarily take part in with such events in order to share the knowledge among others. Dees et al. (2002) also believed that social entrepreneur should focus on the network relationships because these relationships are needed for entrepreneurial performance and to create innovative arrangements to deal with the social problems.

For the question of;

"If you are given a work which is beyond your job, will you prefer to work additional time with an additional effort to upgrade the company profits? Let's assume sometimes you have to go out and may want to stay weeks 
without any personal advantage for you, will you... [Do it for the company]?" (Transcription, focus group 1, September 2015)

Respondents were at focus group -1 raised their voices overwhelming the question. As how they said;

"We have got so many occasions like that. If the company earns profits, it's our own profit." (Focus group 1, September 2015)

They clearly raised their voices to assure their willingness to commit for the company voluntarily. And once they raised their voices, it showed a firm expression and a pitch in their behaviors in order to assure the readiness of working voluntarily. (Field notes, September $27^{\text {th }} 2015$ ) According to Sharir \& Lerner (2006), if workers are ready to work willingly and voluntarily on behalf of the company regardless the economic benefits that they can attain, such companies show a characteristic of social entrepreneurial ventures. Social network is one of the most important factors for successful social entrepreneurship (Jiao, 2011).

According to Tsai \& Ghoshal (1998), the organizational factors in social ventures such as organizational structure, composition of top management team and stability and utilization of social network have a great effect on operations of social entrepreneurship activities. (Jiao, 2011) further delineates that all these factors can be included into social capital of social entrepreneur. Therefore, considering the social entrepreneurial characteristics at IAB it is evident that $\mathrm{IAB}$ consists with a better social network as a social entrepreneurial venture. Further, IAB employees recognize IAB as a best place to work.

Therefore, with the empirical evidences it is confirmed that social entrepreneurship exists in the company of IAB. Hence, the study identifies that the organization as a social entrepreneurial venture by considering the characteristics of the business. 


\section{Discussion and Conclusion}

The case study of International Academy of Beauticians allows a number of important conclusions to be drown on social entrepreneurship in cosmetology industry. Though the concept of social entrepreneurship is problematic due to the absence of agreed universal definition (Light, 2005; Mort, Weerawardena \& Carnegie, 2003; Peredo \& McLean, 2006; Seelos \& Mair, 2005, as cited in Bielefeld, 2009) and different authors bring different views on social entrepreneurship (Light, 2005), the common concepts in definition of social entrepreneurship is assured by the selected case study which elicits that social ventures are with a combination of concepts of entrepreneurship and social mission (Mair \& Marti 2006; Martin \& Osberg 2007) assuring the existing literature.

There, IAB pointed out the female unemployment rate is comparatively high comparing with male unemployment rate in Sri Lanka due to the family commitments and how much it is difficult to run a family with one player who earns for the family. Identifying the opportunity of a lucrative business in hair and beauty therapy as delineated in the analysis the entrepreneur focused towards serving the society by assisting to promote self-employment especially among women to fix the economic condition of the family and to give a good standard of living through a unique education system on selfemployment and to be employed under an employer. According to Dees (1998) education and contribution to economic development are important arenas of social entrepreneurship. Similarly, confirming Jeffs (2006) and Urban (2008) findings on contribution of social entrepreneurs in providing solutions to social, employment and economic problems where traditional market or public approaches fail, case IAB behaves as a social enterprise providing solutions to the all three factors delineated by Jeffs (2006) and Urban (2008).

The case study provides a trendy avenue to the traditional entrepreneurship that offers all the challenges and rewards of traditional entrepreneurship as per Seelos \& Mair (2005) and combined with the vision of changing the society or if not the world. Case of IAB believes that they do a massive contribution to the economy of the country and to the society by promoting 
employment and seeing the opportunity of promoting self-employment as a lucrative business the firm initiated the venture.

At this point, the case study supports the triple bottom line though cosmetology industry. Many are cited that the driving forces of firms with a social mission are to innovate; address unpopular causes; Provide long-term sustainability; take advantages of new opportunities; create entrepreneurial spirit in the organization; show an enhanced understanding of clients (needed for commercial success); enhance an organization's profile among stakeholders through a spur of desire to meet the double bottom line (social value and income) or triple bottom line (social, income and social neutrality) (Bornstein, 2004; Boschee, 2006; Brinkerhoff, 2000; Dees, Emerson \& Economy, 2001, 2002; Robinson, 2002; Tranquada \& Pepin, 2004, as cited in Bielefeld, 2009).

Considering the findings of previous literature, the current study case study proved that the venture is in to entrepreneurship with a social mission. Moreover, it is proved that the case of IAB served the double bottom line by serving the society through promotion of employments and small businesses with a profit orientation.

\section{Theoretical Implications}

Social entrepreneurship as an emerging concept the number of research studies on social entrepreneurship are less. Therefore, a clear definition for social entrepreneurship is still pending. Since different scholars explain the concept in different terms under different contexts, the study focused on deriving an explanation on social entrepreneurship relevant to cosmetology industry in Sri Lanka. Moreover, the current study agreed with the explanations of another set scholars who identify social entrepreneurship as a socially responsible practice of commercial businesses engaged in cross sector partnerships (Sagawa \& Segal, 2000; Waddock, 1988, as cited in Mair $\&$ Marti, 2006).

\section{Managerial Implications}

The study highlights several important practical implications for managers. These, managerial implications delineate the value of social entrepreneurship 
in organizational context. Thus, conclusions of the study bring out important avenues in managerial decision making. As the predominant contribution, the study suggests that social entrepreneurship can be adopted even in cosmetology industry which is highly focused on profitably of own firm. Moreover, social entrepreneurs are becoming a growing source of solutions to issues who provide solutions to social, employment and economic problems where traditional market or public approaches fail. Therefore, it is important to understand that social entrepreneurship as a good source of attaining more profits with a good will rather being reluctant to directly engage with social entrepreneurial endeavors.

\section{References}

Alvord, S. H., Brown, L. D., \& Letts, C. W. (2004). Social entrepreneurship and societal transformation an exploratory study. The journal of applied behavioral science, 40(3), 260-282.

Austin, J. E., Stevenson, H. H., \& Wei-Skillern, J. (2006). Social and commercial entrepreneurship: Same, different, or both? Entrepreneurship: Theory \& Practice, 30(1), 1-22.

Austin, J. E., Stevenson, H. H., \& Wei-Skillern, J. (2003). Social entrepreneurship and commercial entrepreneurship: Same, different, or both? Division of Research, Harvard Business School.

Bhide, A. (2000). The Origin and Evolution of New Business. Oxford University Press: New York.

Bielefeld, W. (2009). Issues in social enterprise and social entrepreneurship. Journal of Public Affairs Education, 69-86.

Bornstein, D. (2004). How to change the world. Social entrepreneurs and the power of new ideas. Oxford: Oxford University Press.

Cavana, R. Y., Delahaye, B. L., \& Sekaran, U. (2001). Applied Business Research: Qualitative and Quantitative Methods (1st Ed.). US \& Australia: John Wiley \& Sons Australia, Ltd 
Creswell, J. W. (2007). Qualitative inquiry and research design: Choosing among five approaches. CA, USA: Sage Publications, Inc.

Dacin, Dacin, \& Tracey. (2011). Social Entrepreneurship: A Critique and Future Directions Organization Science. 22(5), 1203-1213

Dees, G.J. (2001). “The meaning of social entrepreneurship”, Retrieved from; http:// www.caseatduke.org/documents/dees_sedef.pdf

Dees, J. G. (1998). Enterprising nonprofits: What do you do when traditional sources of funding fall short? Harvard Business Review. January/February: 55-67.

Dees, J. G., \& Elias, J. (1998). The challenges of combining social and commercial enterprise. Business Ethics Quarterly, 8(1), 165-178.

Denzin, N. K., \& Lincoln, Y. S. (2003). Introduction: The discipline and practice of qualitative research. Handbook of qualitative re-search (2nd ed., pp. 1-28). Thousand Oaks, CA: Sage Publications.

Harding, R. (2006). Social Entrepreneurship Monitor. London Business School, London.

Haugh, H. (2007). New strategies for a sustainable society: The growing contribution of social entrepreneurship. Business Ethics Quarterly, 17(4), 743-749.

Jeffs, L. (2006, June). Social entrepreneurs and social enterprises: do they have a future in New Zealand. In Conference proceedings from the ICSB world conference.

Jiao, H. (2011). A conceptual model for social entrepreneurship directed toward social impact on society. Social Enterprise Journal, 7(2), 130149.

Langlois, R. N., Cosgel, M. M. (1993). Frank Knight on risk, uncertainty, and the firm: a new interpretation. Economic inquiry, 31(3), 456-465. 
Lesabe, R. A. F., \& Nkosi, J. (2007). A qualitative exploration of employees' views on organizational commitment. SA journal of human resource management, 5(1), 35-44.

Light, P. C. (2005). Searching for social entrepreneurs: Who they might be, where they might be found, what they do. In Draft presented at the Conference of the Association for Research on Nonprofit and Voluntary Organizations, 17-19.

Mair, J., Marti, I. (2006), "Social entrepreneurship research: a source of explanation, prediction, and delight". Journal of World Business, 41, 36-44.

Martin, R. L., \& Osberg, S. (2007). Social entrepreneurship: The case for definition. Stanford Social Innovation Review, 28-39.

Merriam, S. B. (2009). Qualitative research: A guide to design and implementation. San Francisco, CA: Jossey-Bass.

Neuman, W. L. (2011). Social Research Methods: Qualitative and Quantitative Approaches (7th Ed.). USA: Allyn and Bacon, Inc.

Pless, N. M. (2012). Social entrepreneurship in theory and practice-an introduction. Journal of Business Ethics, 111(3), 317-320.

Punch, K. F. (1998). Introduction to Social Research: Quantitative and Qualitative Approaches (1st Ed.). London, Thousand Oaks California, New Delhi: SAGE Publications.

Santos, F. M. (2012). A positive theory of social entrepreneurship, Journal of business ethics, 111(3), 335-351.

Seelos, C.,Mair, J. (2005). Entrepreneurs in service of the poor: Models for business contributions to sustainable development. Business Horizons, 48(3), 241-246. 
Shaw, E., Carter, S. (2007). Social entrepreneurship: Theoretical antecedents and empirical analysis of entrepreneurial processes and outcomes, Journal of small business and enterprise development, 14(3), 418-434.

Spear, R. (2006). "Social entrepreneurship: a different model?", International Journal of Social Economics, 33 (5-6), 399 - 410

Urban, B. (2008). Social entrepreneurship in South Africa: delineating the construct with associated skills. International Journal of Entrepreneurial Behavior \& Research, 14(5), 346-364.

Venkataraman, S. (1997). The distinctive domain of entrepreneurship research. In J. Katz (Ed.), Advances in Entrepreneurship, Firm Emergence and Growth, 3, 119-138. JAI Press.

Zahra, S. A., Rawhouser, H. N., Bhawe, N., Neubaum, D. O., \& Hayton, J. C. (2008). Globalization of social entrepreneurship opportunities, Strategic Entrepreneurship Journal, 2(2), 117-131.

Zahra, S., \& Dess, G. G. (2001). Entrepreneurship as a field of research: Encouraging dialogue and debate. Academy of Management Review, 26(1), 8-10. 